\title{
ИСТОЧНИКИ НЕТРАДИЦИОННЫХ КОРМОВЫХ ДОБАВОК И ИХ ПОЛЕЗНЫЕ СВОЙСТВА
}

\author{
N. A. Tabakov, T. Yu. Savchenko
}

\section{THE SOURCES OF NONCONVENTIONAL FEED ADDITIVES AND THEIR USEFUL PROPERTIES}

Табаков Николай Андреевич - д-р с.-х. наук, профр. каф. зоотехнии и технологии переработки продуктов животноводства Красноярского государственного аграрного университета, г. Красноярск. E-mail: tanya.savchenko.93@inbox.ru

Савченко Татьяна Юрьевна - асп. каф. 300технии и технологии переработки продуктов животноводства Красноярского государственного аграрного университета, г. Красноярск.

E-mail: tanya.savchenko.93@inbox.ru

Цель исследования - определение химического состава нетрадиционных кормовых добавок. Задачи исследования: 1) изучить химический состав нетрадиционных кормовых добавок; 2) определить влияние белитового шлама и окисленного бурого угля на динамику живой массы белых мышей. Исследование проведено в 2018 г. на кафредре зоотехнии и технологии производства продуктов животноводства Института прикладной биотехнологии и ветеринарной медицины Красноярского ГАУ. Объектом исследования являлись нетрадиционные кормовые добавки. Исследование проведено комплексно, с использованием прибора инфрракрасный анализатор «ИнфрраЛЮМ». Экспериментальные данные обработаны методом зоотехнического анализа (лабораторный метод). Для проведения опыта было сфрормировано 3 группы взрослых самок белых мышей по 10 голов в каждой группе, 1 контрольная и 2 опытные. Группы формировались по принципу пар-аналогов с учетом пола, возраста, живой массы, уровня развития и состояния здоровья. Подбор пар-аналогов проводили, руководствуясь методикой А. И. Овсянникова (1976). Контрольная группа получала основной рацион $(\mathrm{OP})$, который включает следующие компоненты: овес, пшеница, крупа кукурузная, хлеб пшеничньй, соль поваренная, морковь, свекла. В первой опьтной группе произведена замена $1 \%$ от минеральной части основного рациона на белитовый шлам. Во второй опытной групnе
Tabakov Nikolay Andreevich - Dr. Agr. Sci., Prof., Chair of Animal Breeding and Technology of Livestock Products Processing, Krasnoyarsk State Agrarian University, Krasnoyarsk.

E-mail: tanya.savchenko.93@inbox.ru

Savchenko Tatyana Yuryevna - Post-Graduate Student, Chair of Animal Breeding and Technology of Livestock Products Processing, Krasnoyarsk State Agrarian University, Krasnoyarsk. E-mail: tanya.savchenko.93@inbox.ru

произведена замена $5 \%$ от минеральной части основного рациона на окисленный бурый уголь. Живая масса в опьтных групnах на конец опьта увеличилась по сравнению с контрольной группой на 4,8 и на 7,9 2, что составляет 18,1 и $28,4 \%$ соответственно ( $P \geq 0,999)$. Нетрадиционные кормовые добавки, содержащие большое количество минеральных элементов, оказали положительное влияние на прирост живой массы лабораторных животных (бельх мышей).

Ключевые слова: кормовые добавки, животноводство, химический состав нетрадиционных кормовых добавок.

The research objective was the definition of chemical composition of nonconventional feed additives. The research problems were: 1) to study chemical composition of nonconventional feed additives; 2) to define the influence of belite slime and oxidized brown coal on the dynamics of live mass of white mice. The research was conducted in 2018 on the Department of Animal Breeding and Production Technology of Livestock Products of the Institute of Applied Biotechnology and Veterinary Medicine of Krasnoyarsk SAU. The objects of the research were nonconventional feed additives. The research was conducted in complex with using the device of the infrared Infralyum analyzer. Experimental data were processed by the method of zootechnical analysis (laboratory method). For carrying out the experiment 3 groups of adult females of white mice up to 10 
heads in each group, one control and two experimental were made. The groups were formed by the principle of the couple's analogs taking into account the sex, age, live weight, development level of and the state of health. The selection of couples analogs was carried out, using A.I. Ovsyannikov technique. (1976). Control group received the main diet (MD) which included the following components: oats, wheat, grain corn, white bread, table salt, carrots and beet. In the first experimental group the replacement of $1 \%$ of mineral part of the main diet by belite slime was made. In the second experimental group the replacement of $5 \%$ of mineral part of the main diet by oxidized brown coal was performed. Live weight in experimental groups by the end of experiment increased in comparison with control group by 4.8 and by $7.9 \mathrm{~g}$ that made 18.1 and $28.4 \%$, respectively $(P \geq 0.999)$. Nonconventional feed additives containing a large number of mineral elements had positive impact on the gain of live mass of laboratory animals (white mice).

Keywords: feed additives, animal husbandry, chemical composition of nonconventional feed additives.

Введение. В настоящие время использование различных нетрадиционных источников для кормления сельскохозяйственных животных повышающих качественные и количественные показатели продуктивности является актуальной.

Красноярский край богат различными сырьевыми ресурсами, из которых можно получать кормовые добавки, являющиеся полноценными заменителями синтетически разработанных добавок.
Правильно подобранное сырье, богатое определенным химическим составом, позволяет в дальнейшем получать качественные недорогие добавки.

Таким образом, изучение химического состава из нетрадиционных источников местного сырья позволит получить разнообразные добавки, которые повысят качественный и количественный состав у изучаемых животных.

Цель исследования: изучить химический состав нетрадиционных кормовых добавок.

Задачи исследования:

1. Изучить источники и химический состав нетрадиционных кормовых добавок.

2. Определить влияние белитового шлама и окисленного бурого угля на динамику живой массы белых мышей.

Объект и методы исследования. Исследование проведено в 2018 г. на кафедре зоотехнии и технологии производства продуктов животноводства Института прикладной биотехнологии и ветеринарной медицины Красноярского ГАУ. Объектом исследования являлись нетрадиционные кормовые добавки.

Исследование проведено комплексно, с использованием прибора инфракрасный анализатор «ИнфраЛЮМ». Инфракрасный анализатор - лабораторный прибор, предназначенный для проведения экспресс-анализа качества кормов и кормовых добавок.

Результаты исследования и их обсуждение. Результаты исследования химического состава нетрадиционных кормовых добавок представлены в таблице 1.

Таблица 1

Химический состав нетрадиционных кормовых добавок

\begin{tabular}{|l|c|c|c|c|c|}
\hline \multirow{2}{*}{ Показатель } & \multicolumn{5}{|c|}{ Содержится, г/кг } \\
\cline { 2 - 6 } & Окисленный бурый уголь & Белитовый шлам & Вермикулит & Сапропель & Торф \\
\hline \multicolumn{1}{c|}{1} & 2 & 3 & 4 & 5 & 6 \\
\hline Алюминий & 0 & - & 0,175 & 0 & 0 \\
\hline Железо & 0,345 & 0,0015 & 0,0012 & 5,7 & 0,0016 \\
\hline Калий & 0,00018 & 0,00142 & 0,079 & 2,2 & 0,00073 \\
\hline Кальций & 0,0054 & 0,00938 & 0,0015 & 2,5 & 0,005 \\
\hline Кобальт & 0 & 0,000015 & 0 & 0 & 0 \\
\hline Кремний & 0 & 0 & 0,049 & 0 & 0 \\
\hline Магний & 0,000268 & 0,00083 & 0,0235 & 1,2 & 0,0007 \\
\hline Марганец & 0,08 & 0,0039 & 0,0003 & 215,5 & 0,38 \\
\hline
\end{tabular}




\begin{tabular}{|l|c|c|c|c|c|}
\multicolumn{1}{|c|}{1} & 2 & 3 & 4 & 5 & Окончание табл. 1 \\
\hline Медь & 0,057 & 0,000033 & 0 & 7,8 & 0,085 \\
\hline Натрий & 0,075 & 0,00049 & 0,0008 & 3,4 & 0,0038 \\
\hline Селен & 0 & 0,0001 & 0 & 0 & 0 \\
\hline Сера & 0 & 0,00037 & 0,0002 & 0 & 0 \\
\hline Углерод & 0 & 0 & 0,0006 & 0 & 0 \\
\hline Фосфрор & 0,00069 & 0,00086 & 0 & 0,14 & 0,0006 \\
\hline Хлор & 0 & 0 & 0,0005 & 0 & 0 \\
\hline Хром & 0 & 0 & 0,0005 & 0 & 0 \\
\hline Цинк & 0,0265 & 0,00009 & 0 & 16,6 & 0,025 \\
\hline $\begin{array}{l}\text { Гуминовые } \\
\text { кислоты }\end{array}$ & 0,85 & 0 & 0 & 0,712 & 15,19 \\
\hline
\end{tabular}

Окисленный бурый уголь является более богатым природным источником гуминовых веществ. Представляет из себя природное ископаемое, формирующееся в земле уже миллионы лет, благодаря химическим и биологическим разложениям доисторических растений и животных. Содержание гуминовых веществ в нем составляет до $85 \%$. В состав гуматных препаратов входят полисахариды, пептиды, аминокислоты, фульвокислоты и гиматомелановые кислоты, микро- и макроэлементы (калий, фосфрор), белки, витамины, ферменты. Благодаря легкодоступной для живых организмов форме, гуматы способны быстро влиять на обменные процессы в клетках, повышать иммунные и другие жизненно важные свойства, т. е. они являются естественными стимуляторами роста и продуктивности $[4,8]$.

Положительное влияние гуматов (калия и натрия) на растительные организмы подтвердило их биологическую активность, что способствовало увеличению энергетики клеток, улучшению обменных процессов в них в сочетании с экологической чистотой и безопасностью.

Белитовый шлам представляет из себя порошок серого цвета, который получается в итоге переработки и обогащения алюминийсодержащих глин.

В белитовом шламе Ачинского алюминиевого глиноземного комбината содержатся элементы [1]:

- Вермикулит - минерал из группы гидрослюд, водный алюмосиликат магния и железа. Появляется при выветривании щелочных слюд биотита и фрлогопита. В Красноярском крае в пределах Восточного Саяна известно одно месторождение (Размановское) и два проявления
(Караганское и Кингашское). Вермикулитовые месторождения представлены линзо- и пластообразными крутопадающими телами вермикулита. Обычно вермикулит содержится в виде линз, цепочек, слойков, прожилков либо в тонкорассеянном виде в массе пород. По результатам технико-экономических расчетов сделан вывод о нецелесообразности промышленной разработки этих месторождений из-за высокой стоимости продукции, что обусловлено небольшими запасами сырья [5].

- Сапропель (сапропель кормовой) - значимая кормовая добавка для животных и птиц, содержащая набор специальных биологически активных веществ, повышающих производительность свиней, крупного рогатого скота и птицы, а также устойчивость к различным болезням. Сапропель кормовой в естественном виде влажностью не более $65 \%$ предназначен для использования в качестве кормовой добавки в рационе всех видов животных и птиц.

Сухой сапропель кормовой может использоваться в комбикормовой промышленности при производстве всех видов комбикормов как кормовая органо-минеральная добавка (премикс) и в качестве наполнителя при изготовлении витаминных премиксов [6].

Сапропель применятся в качестве кормовой добавки не только для снижения расхода корма, но также и с целью обогащения рациона минеральными веществами, аминокислотами, витаминами и биологически функциональными веществами. Сапропели - органо-минеральные отложения озерных водоемов оливковобурового, светло-серого, темно-коричневого, кремового цветов, студенистые, жирные на 
ощупь. Сапропели представляют собой ценную витаминно-минеральную кормовую добавку.

В Красноярском крае выявлено 29 месторождений озерных сапропелей, по которым подсчитаны прогнозные ресурсы. Минеральный состав - известковистый или кремнисто-известковистый, содержание фттора - до 0,2 \%; зольность сапропеля разнообразная - от 14 до 66 \% [7].

Торф является ингибитором окисления растительных и животных жиров и применяется в качестве стабилизирующей, предотвращающей окислительную порчу добавки к жиросодержащим кормам.

Гуминовые кислоты, находящиеся в торфе, активизируют жизнедеятельность микрофрлоры кишечного тракта, увеличивают показатель использования питательных компонентов кормов, ускоряют рост и развитие организма, активизируют обмен веществ, углеводный и белковый метаболизм, увеличивают естественную резистентность организма, нормализуют кислотный баланс в организме $[1,8]$.

Кислоты имеют антисептические свойства и хорошую фильтрацию. В составе верхового торфа в достаточном количестве присутствуют гуминовые кислоты.

Для проведения опыта было сформировано 3 группы взрослых самок белых мышей по 10 голов в каждой группе, одна контрольная и две опытные (табл. 2). Группы формировались по принципу пар-аналогов с учетом пола, возраста, живой массы, уровня развития и состояния здоровья. Подбор пар-аналогов проводили, руководствуясь методикой А. И. Овсянникова (1976) [2].

Таблица 2

\section{Схема проведения опыта}

\begin{tabular}{|l|c|c|c|}
\hline \multicolumn{1}{|c|}{ Группа } & $\begin{array}{c}\text { Кол-во мышей } \\
\text { в группе, голов }\end{array}$ & Условия кормления & $\begin{array}{c}\text { Продолжительность } \\
\text { периодов, дней }\end{array}$ \\
\cline { 1 - 2 } Контрольная & 10 & ОР & \multirow{2}{*}{60} \\
\cline { 1 - 2 } І опытная & 10 & ОР +1\% белитового шлама & \\
\hline ІІ опытная & 10 & ОР $+5 \%$ окисленного бурого угля & \\
\hline
\end{tabular}

Контрольная группа получала основной рацион (ОР), который включает следующие компоненты: овес, пшеница, крупа кукурузная, хлеб пшеничный, соль поваренная, морковь, свекла. В первой опытной группе произведена замена $1 \%$ от минеральной части основного рациона на бе- литовый шлам. Во второй опытной группе произведена замена $5 \%$ от минеральной части основного рациона на окисленный бурый уголь.

Результаты исследования прироста живой массы лабораторных животных (белых мышей) представлены в таблице 3.

Таблица 3

\section{Живая масса лабораторных животных}

\begin{tabular}{|l|c|c|c|}
\hline \multirow{2}{*}{ Показатель } & \multicolumn{3}{|c|}{ Группа } \\
\cline { 2 - 4 } & Контрольная & $\begin{array}{c}\text { 1-я опытная } \\
\text { (белитовый шлам) } 1 \%\end{array}$ & $\begin{array}{c}\text { 2-я опытная (окис- } \\
\text { ленный бурый уголь) } \\
5 \%\end{array}$ \\
\hline Живая масса, г: & & & $24,93 \pm 0,02$ \\
\hline в первый день опыта & $24.93 \pm 0,02$ & $24,88 \pm 0,03^{* * *}$ & $28,28 \pm 0,02^{* * *}$ \\
\hline через 7 дней & $25,66 \pm 0,05$ & $27,05 \pm 0,02^{* * *}$ & $31,71 \pm 0,03^{* * *}$ \\
\hline через 14 дней & $26,89 \pm 0,03$ & $29,3 \pm 0,03^{* * *}$ & $34,01 \pm 0,02^{* * *}$ \\
\hline через 21 день & $28,9 \pm 0,02$ & $32,11 \pm 0,05^{* * *}$ & $38,6 \pm 0,04^{* *}$ \\
\hline через 28 дней & $30,07 \pm 0,02$ & $35,52 \pm 0,04^{* * *}$ & 0,48 \\
\hline Среднесуточный прирост, г & 0,2 & 0,38 & \\
\hline
\end{tabular}

Примечание: ${ }^{*} \mathrm{P}>0,95 ;{ }^{* *} \mathrm{P}>0,99 ;{ }^{* * *} \mathrm{P}>0,999$ по отношению к контрольной группе. 
Исходя из данных таблицы 3, живая масса в опытных группах изменилась. На конец опыта живая масса увеличилась по сравнению с контрольной группой на 4,8 и на 7,9 г, что составило 18,1 и $28,4 \%$ соответственно ( $P \geq 0,999)$.

Выводы. Таким образом, нетрадиционные кормовые добавки содержащие большое количество минеральных элементов, оказали положительное влияние на прирост живой массы лабораторных животных (белых мышей).

\section{Литература}

1. Богомолов A.B. Белитовый шлам - отходы глиноземного производства в кормлении сельскохозяйственных животных // Студенческая наука - взгляд в будущее: мат-лы XII Всерос. студ. науч. конф., посвящ. Году экологии и 65-летию Красноярского ГАУ. Ч. 2 I Краснояр. гос. аграр. ун-т. Красноярск, 2017. C. 147-148.

2. Овсянников А.И. Основы опытного дела в животноводстве. М.: Колос, 1976. 304 с.

3. Савык Т.Л. Нетрадиционные добавки для животных // Кормороизводство. 1998. № 8. C. 30-31.

4. Савченко Т.Ю. Органо-минеральные соединения как источник оптимизации в животноводстве // Студенческая наука - взгляд в будущее: мат-лы XII Всерос. студ. науч. конф., посвящ. Году экологии и 65-летию Красноярского ГАУ. Ч. 2 / Краснояр. гос. аграр. ун-т. Красноярск, 2017. С. 190-192.

5. Солнцев М. Комплексное использование биологически активных веществ в кормлении сельскохозяйственных животных. Горки, 2009. С. 122.

6. Табаков Н.А., Скуковский Б.А., Тюрина Л.Е. Местные источники биологически активных веществ и рациональное использование в кормлении сельскохозяйственных животных / Краснояр. гос. аграр. ун-т. Красноярск, 2017. C. 7.
7. URL: https://yandex.ru/znatoki/question/garden/ sapropel_chto_eto_takoe_i_kak_ispolzovat_a8 03a584/?utm_source=yandex\&utm_medium $=w$ izard\#86e16845-fc8f-4fb1-abc5-38fd5823fc6f.

8. URL: https://cyberleninka.ru/article/n/vydelenie -guminovyh-kislot-iz-okislennyh-buryh-ugley-iih-sorbtsionnye-svoystva.

\section{Literatura}

1. Bogomolov A.V. Belitovyj shlam - othody glinozemnogo proizvodstva $v$ kormlenii sel'skohozjajstvennyh zhivotnyh // Studencheskaja nauka - vzgljad $v$ budushhee: mat-ly HII Vseros. stud. nauch. konf., posvjashh. Godu jekologii i 65-letiju Krasnojarskogo GAU. Ch. 2 I Krasnojar. gos. agrar. un-t. Krasnojarsk, 2017. S. 147-148.

2. Ovsjannikov A.l. Osnovy opytnogo dela v zhivotnovodstve. M.: Kolos, 1976. $304 \mathrm{~s}$.

3. Savyk T.L. Netradicionnye dobavki dlja zhivotnyh // Kormoroizvodstvo. 1998. № 8. S. 30-31.

4. Savchenko T.Ju. Organomineral'nye soedinenija kak istochnik optimizacii $\mathrm{v}$ zhivotnovodstve // Studencheskaja nauka - vzgljad v budushhee: mat-ly HII Vseros. stud. nauch. konf., posvjashh. Godu jekologii i 65-letiju Krasnojarskogo GAU. Ch. 2 / Krasnojar. gos. agrar. un-t. Krasnojarsk, 2017. S. 190-192.

5. Solncev M. Kompleksnoe ispol'zovanie biologicheski aktivnyh veshhestv v kormlenii sel'skohozjajstvennyh zhivotnyh. Gorki, 2009. S. 122.

6. Tabakov N.A., Skukovskij B.A., Tjurina L.E. Mestnye istochniki biologicheski aktivnyh veshhestv i racional'noe ispol'zovanie v kormlenii sel'skohozjajstvennyh zhivotnyh / Krasnojar. gos. agrar. un-t. Krasnojarsk, 2017. S. 7.

7. URL: https://yandex.ru/znatoki/question/garden/ sapropel_chto_eto_takoe_i_kak_ispolzovat_a8 03a584/?utm_source=yandex\&utm_medium $=w$ izard\#86e 16845-fc8f-4fb1-abc5-38fd5823fc6f.

8. URL: https://cyberleninka.ru/article/n/vydelenieguminovyh-kislot-iz-okislennyh-buryh-ugley-i-ihsorbtsionnye-svoystva. 